\title{
SEDENTARY AND BEDOUIN DIALECTS IN CONTACT: REMARKS ON KARAKI AND SALṬI (JORDAN)
}

\author{
Heikki Palva
}

\section{UNIVERSITY OF HELSINKI}

El-Karak and es-Salt are two Jordanian towns which have traditionally been in close contact with Bedouin neighbours. Part of their population also claims Bedouin origin. The dialects spoken in the towns can be classified as rural dialects of mixed type. They display a number of Bedouin-type features, e.g. the voiced $g$ variant of $*$. The Bedouin traits of Karaki are typical of the dialects spoken in Arabia Petraea, in Salți they belong to the dialects of the Syro-Mesopotamian group. Diachronically, some of the features shared with Bedouin dialects may be regarded as conservative sedentary traits, e.g. the retention of interdentals as well as gender distinction in plural of finite verbs and personal pronouns. Both Karaki and Salți use the $b$ imperfect, whereas they differ from each other in the use of negations. Salti makes use of the compound negation, in Karaki it is not used.

\section{Introduction}

0.1. El-Karak and es-Salt are ancient towns known from biblical times. Today both are important administrative centres in the Hashemite Kingdom of Jordan. El-Karak lies about sixteen kilometres east of the southern end of the Dead Sea, and es-Salt is situated about twenty kilometres east of the river Jordan, and about twenty-five northwest of Amman. In the context of this article the ancient history of the towns is irrelevant; the most pertinent history to the comparative study of their dialects is that they have been uninterruptedly inhabited since the end of the Crusades.

Both towns have a Muslim majority and a Christian minority, the latter varying between seven and twelve per cent, and the relations between the local Muslims and Christians have always been friendly and close. ${ }^{1}$ In Central and Southern Jordan the fabric of the traditional society does not depend on religious affiliation, but it follows the lines of the tribal structure of Bedouin society. Oppenheim describes the traditional society of the sedentary population in these areas as follows:

The sedentary population can in a sense also be regarded as Bedouin. The townspeople and fellăhin in the districts to the south of ${ }^{\mathrm{c}}$ Ajlūn share the lan-

\footnotetext{
${ }^{1}$ Gubser 1973, 63 (el-Karak); Dā̄ōd 1994, 227 (es-Salt).
} 
guage, the manners and customs as well as the tribal structure with the Bedouin. In spite of that, all of them are not of Bedouin origin, but they represent to a great extent an originally sedentary population, which has over time been bedouinized. This is a phenomenon which does not exist in this degree in any country dealt with by now. It is worthy of note that this is true of the Christians as well. In Șalt (sic), Mādebā and Kerak they are organized in tribes and are not second to their Muslim neighbours in military power. ${ }^{2}$

The merchants have traditionally not been members of tribal alliances but have lived as independent extended families, maintaining considerable common contact in business and social affairs. On the other hand, they naturally have close ties with their clans in other towns. ${ }^{3}$

Part of the Muslim population claim sedentary, and part of it Bedouin origin. A typical case is the background of the Majāli, the leading clan in el-Karak and also prominent in the whole country. They claim descent from the Najdi tribe of Tamìm, but the most credible among the varying stories are the traditions which tell that they first came to el-Karak from Hebron as a group of merchants around the year $1700 .{ }^{4}$ In es-Salt, a corresponding case is the clan of el-Klūb who claim descent from the ancient tribe of Banu Kalb. These claims, obviously connected with the prestige given by Bedouin descent, are as impossible to prove as several Christian clans' claims of pre-Islamic Ghassanid origins. It is, however, apparent that Bedouin origins are much more common in es-Salt than in el-Karak. During the Ottoman period many Bedouin families settled at es-Salț: the clan of el- ${ }^{\mathrm{c}}$ Arabīyāt is said to have Šammari background, elJazzāzīye claim descent from the Wild ${ }^{\mathrm{c}} \mathrm{Ali}$; el- ${ }^{\mathrm{c}} \mathrm{Abdalla}$ and el-Mašāmše are said to have come from al-Jawf, en-Najādwa from Najd, and elKhrēsāt from the Hijāz. In any case, the most powerful Salti clans are of Palestinian origin. Part of the important clan of the ${ }^{\mathrm{c}} \mathrm{Aw}$ āmle are reported to have come from Palestine in the sixteenth century; the first family of the Qtẹēāt came from Hebron about the year 1600, and most of el-Krād probably came in the seventeenth century, from Palestine as well. ${ }^{5}$

2 Oppenheim 1943, 184; see also Burckhardt 1822, 382.

${ }^{3}$ Gubser 1973, 67.

${ }^{4}$ Musil 1908, 84-85, 97; Peake 1958, 188-192; Gubser 1973, 15. According to Oppenheim $(1943,260)$, the first emigration of the Majāli 'exiles' from Hebron may have taken place in 1473 , when a number of notable persons were exiled.

5 Peake 1958, 178-182. According to Khuraysāt (1986, 68), the first Muslim inhabitants after the Crusader era were Kurds from Hakkari, who had participated in Salāh al-Dīn's operations against the Crusaders in the Jordan 
Most of the Christian clans hail from Palestine. In el-Karak, many of them have come from Hebron, Bethlehem and Jerusalem, while in esSalt many derive their roots from immigrants from Central Palestine, but also from Lebanon, Damascus, ${ }^{~}$ Ajlūn, Ḥōrān, and el-Karak. ${ }^{6}$

0.2. In the chaotic conditions prevailing in Transjordan at the beginning of the Ottoman rule, es-Salt remained the only village in al-Balqa $\overline{ }^{\supset}$ that could look after itself; all other villages were deserted. According to the Ottoman assessment rolls from the end of the sixteenth century, es-Salt was the only market centre in al-Balqā ${ }^{-}$. In the south, el-Karak had a similar position. On these markets, turnover was not very high, only four to eight percent of the sales figure of Nāblus and Jerusalem, not to speak about Gaza. The number of inhabitants in the whole Transjordanian area was not more than 51,000, the majority of which lived in ${ }^{\mathrm{c}}$ Ajlūn. ${ }^{7}$ According to Burckhardt, the population of el-Karak in 1812 was about four hundred Muslim and one hundred and fifty Christian families, and that of es-Salt about four hundred Muslim, and eighty Christian families. $^{8}$

Since the beginning of the Ottoman rule, el-Karak decreased in importance, not least because the Ottomans moved the Pilgrim Road from the King's Highway to the east, to the route of the later Hijāz Railway. Consequently, the Ottomans had no interest to interfere in the affairs of elKarak, and the town was left virtually independent. Commercial contacts to Palestine were mainly maintained with Jerusalem by merchants who were from Hebron. According to Burckhardt, who visited the town in 1812, six caravans a year were sent to Jerusalem. ${ }^{9}$ Practically the whole period of the Karaki 'independence,' that is, until 1893, when the Ottomans reoccupied the town, most merchants in el-Karak were Hebronis. ${ }^{10}$ After the incorporation of el-Karak into the Ottoman administration, the contacts to the north increased, and many new merchants came to the town from Damascus. After 1948 many Ghazzawis immigrated to el-

Valley. They have given their name to the Mahallat al-Akrād quarter between the castle and the Great Mosque; for maps illustrating the residential areas in esSalt at the beginning and at the end of the Ottoman era, see $\overline{D a}^{\top} \overline{\mathrm{u}} \mathrm{d} 1994,246-$ 247.

6 Peake 1958, 180-182, 191.

7 Hütteroth 1978, 21, 28.

8 Burckhardt 1822, 349, 381.

9 Ibid., 388.

10 Gubser 1973, 36, 67-68. 
Karak, and are now the dominant group within the merchant class. ${ }^{11}$

In the seventeenth, eighteenth, and nineteenth century too es-Salt was virtually independent from the Ottoman state. ${ }^{12}$ The merchants of the town had almost daily contacts with Jerusalem and Nāblus, with the latter to the extent that es-Salt was characterized as 'another Nablus', Nābulus at-tanniya. ${ }^{13}$ Also at the end of the nineteenth and at the beginning of the twentieth century, contacts were lively as appears from the carefully documented data given by $D \bar{a}^{\top} \bar{u} d$. In the years $1880-1915$ as many as seventy-six families from Nablus and nineteen from Jerusalem moved to es-Salț. The number of immigrant families from Hebron was seven, from Nazareth three, from Bethlehem, Lydda, and Jenin one. During the same period the trade with Syria was brisk, as is evident from the number of immigrant families from Syria and Lebanon, thirty-two and four, respectively. ${ }^{14}$

0.3. As mentioned above, according to Oppenheim, the sedentary population in central and southern Transjordan - except Amman, of courseshare the language with the Bedouin. This was also Burckhardt's view two hundred years ago. During his stay at es-Salt in 1812 he noted that 'their language is the true Bedouin dialect'. ${ }^{15}$ As is typical of these kinds of impressionistic descriptions, no linguistic data are given. The least we can suppose is that the reflex of ${ }^{*} \mathrm{q}$ must have been $g$ and that $* \mathrm{k}$ had an affricated variant. Some Bedouin lexical items probably contributed to the general impression. Also in el-Karak the inhabitants according to Burckhardt 'exactly resemble, in dress, food, and language' the neighbouring Bedouin tribes. ${ }^{16}$ The dialects of these tribes belong to the Northwest Arabian type ${ }^{17}$ represented by the Negev and Sinai dialects as well as by the dialect(s) of the Hwettāt and Bani ${ }^{c}$ Ațiyye, whereas the Bedouin neighbours of es-Salt speak dialects of the Syro-Mesopotamian (the ${ }^{\mathrm{c}}$ Adwān and Bani ${ }^{\mathrm{c}} \mathrm{Abbād}$ ) and North Arabian (the Bani Șakhr) dialect groups. ${ }^{18}$

\footnotetext{
${ }^{11}$ Ibid., 36.

12 Burckhardt 1822, 349.

13 Dā̄ōd 1994, 561.

${ }^{14}$ Ibid., 248-270.

15 Burckhardt 1822, 351; for the linguistic observations of the explorers, see Palva 1997.

16 Burckhardt 1822, 388.

17 Palva 1991; id. 2008.

18 The Jordanian data given without reference are based on published and
} 
During my field studies in es-Salt and the adjacent villages ${ }^{19}$ it turned out to be very difficult to find any dialectal differences between the Muslims and the Christians. Some informants claimed that they actually could identify the sociolects of these groups on grounds of the pronunciation of certain individual items: /u/ vs. /i/: 'he writes' buktub Muslim vs. biktib Christian; /i/ vs. /u/: 'I saw' šift $\mathrm{M}$ vs. šuft C; 'window' šibbāk $\mathrm{M}$ vs. šubbāk C; 'mouth' timm M vs. țumm C. Thus it would seem that the $/ \mathrm{i} / \mathrm{vs}$. /u/ contrast sometimes serves - or has served - as a distinctive linguistic marker between the different religious groups, which might reflect earlier dialect differences due to the varying origins of the Salti clans. Although I feel rather uncertain about the accuracy of these sporadic pieces of information, they are to some extent corroborated by the instance buktub et-Tafîle (M, south of el-Karak) vs. biktib Mādaba ${ }^{20}$ (C, originally emigrants from el-Karak in 1880). ${ }^{21}$ On the other hand, however, I have attested only țumm for Mādaba, el-Karak and et-Tafîle, irrespective of religious affiliation; unfortunately, I failed to take notes for the

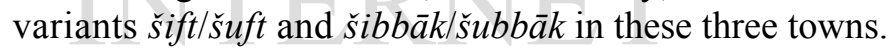

1. The dialect of el-Karak ${ }^{22}$

1.1. Sedentary features in Karaki

The stress patterns and syllable structure are essentially identical with those obtaining in Palestinian sedentary dialects:

- no -aXC $\longrightarrow-\mathrm{aXaC}$, or 'gahawa syndrome': gahwa, ya'rif, yac (a)rfu vs. gaháwah, ya $a r f, y a^{c}$ arfu the Negev; ${ }^{23} g(a) h a ́ w a, y(a)^{c} a r f, y(a)^{c}$ arfu Hộetị; ${ }^{24}$

- no resyllabification rule CaCaCV- $\longrightarrow$ CCVCV-: katabat, katabu, zalame vs. kitábat, kitábaw, zalámah/zálamah the Negev; kitábat, kitábow; zluma Hiweți;

- katab, without low vowel raising in the initial syllable, cf. kitáb the Negev, kitab Hwêți; retained /a/ even in the $f^{c} i l$ - perfect base: šarib, šarbet; šaribt, šaribti; šaribt; šarbu, šarbin; šaribtu, šaribtin; šaribna;

- the definite article does not occur as an integral part of the phonetic

unpublished material of my own.

${ }^{19}$ Numerous short periods of two to seven weeks between 1965 and 1992.

20 The data on Mādaba and et-Tafīle are based on own observations.

${ }^{21}$ Musil 1908, 94-96; Jaussen 1948, 417-440.

22 The Karaki data are based on Palva 1989.

23 The Negev data are based on Blanc 1970 but are to be found in Henkin 2008 as well.

24 All Hwēẹi data are based on Palva 1984-86 and id. 2008. 
word, that is, it is not stressable like in Hwetti and the Bedouin dialects of Sinai and the Negev which have álbil 'the camels', álwalad 'the boy, the son', álbahar 'the sea'.

In verbal morphology, the following typologically important features are markedly sedentary traits:

- the $b$-imperfect is regularly used to denote indicative non-past action and non-contingency; this is probably an inherited local sedentary trait shared by Palestinian dialects, rather than a recent borrowing from Palestine; e.g. the imperfect form of $g \bar{a} l$ : 3 rd p. sg.m. bugūl, 1st p. pl. bingūl as in rural south Palestinian; this contrasts with Hwêtị which does not have the $b$-imperfect, but not with the Bedouin dialects of Sinai and the Negev which have it;

- bōkil, bōxud (as if from *wakal, *waxad) as in Palestinian dialects (vs. $b \bar{a}$-: Syria, Lebanon, Upper Galilee, Jerusalem, Hebron, Gaza; yō- Ḥōrān and the oases) vs. Bedouin yākil, yāxud..$^{25}$

Further sedentary features include the following examples:

- the long forms of the personal pronouns of the 3rd persons, $h \bar{u}(w a)$, hì (ye), huтmu, hinne, i.e., the same as in Mādaba and es-Salt (*hum(m) $+-u,{ }^{26}$ not found in Syria ${ }^{27}$ ), not attested in neighbouring Bedouin dialects, which have short forms only: hī, hì, hum, hin; cf. central and southern Palestine $h \bar{u}(w e), h \bar{\imath}(y e)$, urban pl.c. hunne, rural m. humme, f. hinne ${ }^{28}$ hü/huwwa, hï/hiyye, humm/humme, hinn/hinne; ${ }^{29}$

- hēk 'this way, so' may be a koine form ('K-form'), but the form $h \bar{e}<$ $h \bar{e} \underline{d}$, occurring side by side with it, probably is genuine; $h \bar{e} \underline{d}$ *hādd $\underline{a} \bar{a}<$ *hākd $\bar{d} \bar{a}$ (the vowel has probably been taken over from $h \bar{e} k^{30}$ ) is, as is well known, a rural central Palestinian item, e.g. Bīr Zèt hēe h, héd $\underline{d} a$, $h \bar{e} \underline{d} \underline{d} \bar{a} k ;^{31}$

- émta * ayy matā 'when?' is a sedentary item, contrasting with the Bedouin mita/mata; cf. south Palestine waqtěs, northwest, central and lower Galilee wèmta, Syria, Lebanon, part of the Jordan Valley, Jerusalem èmta; ${ }^{32}$

25 Bergsträsser 1915, map 19; Behnstedt 1997, map 174.

26 Perhaps associated with the plural morpheme of verbal inflection.

27 Behnstedt 1997, map 257.

28 Bauer 1926, 67.

${ }^{29}$ Cleveland 1967, 53.

${ }^{30}$ Fischer 1959, 142.

${ }^{31}$ Schmidt and Kahle 1918, 48, line 6; 170, line 1; 174, line 26.

32 Bergsträsser 1915, map 26; Behnstedt 1997, map 290. 


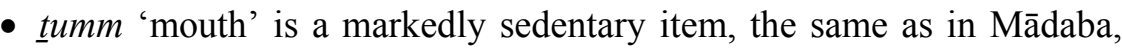
et-T Tafile and rural south Palestinian; ${ }^{33}$ the Galilee timm; cf. afām, afám the Negev and Sinai, afám Hweți, fam ${ }^{\mathrm{c} A n a z i, ~ a f a m ~ S ̌ a m m a r i, ~ i t i m ~ t h e ~}$ Syro-Mesopotamian Bedouin and the Bani Șakhr. ${ }^{34}$ In central and western Syria the form is tumm, in Damascus timm, in Damascus Plain tumm, in most of the Qalamūn mountains and Ḥōān tumm, and in Palmyra and the neighbouring Bedouin itum. ${ }^{35}$

\subsection{Bedouin features in Karaki}

- $g$ without affricated variant as the reflex of *q, like in the Bedouin dialects of the Northwest Arabian type as well as in rural South Palestinian; vs. northern and Syro-Mesopotamian Bedouin dialects;

- $k$ as the reflex of $* \mathrm{k}$ without an affricated variant, as in the Bedouin dialects of Sinai, the Negev, the Hwettât and Bani ${ }^{c}$ Ațiyye. The only exception to the rule is čân, čann-, inčān 'if,' which is used side by side with $k \bar{a} n$, inkān. The affricated variant is probably a loan from dialects which use the affrication, but this is somewhat problematic since the Bedouin dialects of the adjacent area do not affricate $* k$, neither do the south Palestinian dialects. However, the relevant language contacts are not restricted to the bordering neighbours alone.

There are a number of additional Bedouin features in Karaki, but it is typical of them that they as a rule appear side by side with sedentarytype items:

- ams, used alongside the sedentary item imbārih , both in the meaning 'yesterday', whereas ams in Bedouin dialects means 'yesterday' and albārih stands for 'yesterday evening'. ${ }^{36}$ In Soukhne, where 'yesterday' is mbirih, also ams is used, but in the meaning 'lately', 'a couple of days ago' ${ }^{37}$ Cantineau has attested ams in Irbid as well, but doubts its genuineness. ${ }^{38}$ Central and south Syria have mbarihh, north Syria mbērha, coastal Syria and Palmyra mbērih̆, Syrian Bedouin albärih. ${ }^{39}$

- $y \bar{o} m$, temporal conjunction 'when', used side by side with the sedentary Palestinian lamma;

- wēš, wē, mšān wē, mšān wēš 'what?' used alongside the sedentary Pales-

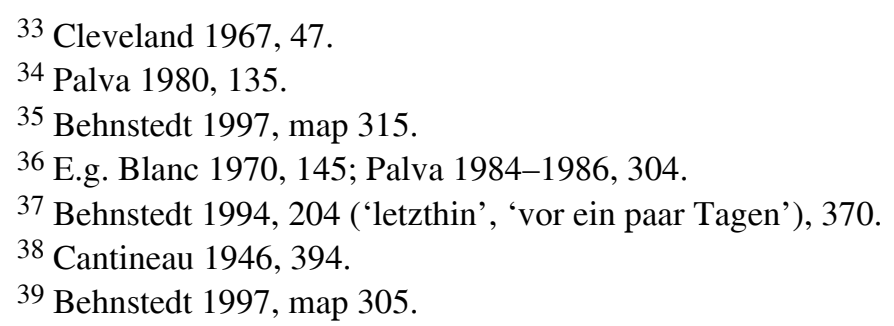


tinian $\check{s} \bar{u}, \bar{e} s ̌$; $w e \bar{s} s$ el-Karak, Ma ${ }^{\mathrm{c}} \overline{\mathrm{a}}$ and 'Bedouin'; ${ }^{40}$ cf. the Syrian Bedouin residue of tanwīn: šinu, šinhu, šnu, ešnu; ${ }^{41}$ Bani Șakhr wišs, wuš, wišinh $\bar{u}$; 42 the Hwêtāat wuš, side by side with the K-forms $\bar{e} \breve{s}$ and $\check{s} \bar{u}$, proclitically $i \check{s}$ and $\check{s} u$; the Negev ayš mostly as sentence word, $\bar{e} \check{s} / \check{\imath} \breve{s}$ before verbs, wiš in short nominal sentences; el- ${ }^{\mathrm{c}} \mathrm{Ajārma} w \partial \check{s}, \mathrm{~K}$-forms $\bar{e} \bar{s} / \partial \check{s}$, $\check{s} \bar{u} / s ̌ s ; 4$

- lē, lye ' why?' used side by side with the sedentary lēs, lwēš;

- badri 'early,' used side by side with the sedentary-type item bakkìr.

\subsection{Conservative and locally restricted features in Karaki}

- as in all sedentary dialects of the Greater Syrian dialect area, the older $/ \mathrm{i} /$ and $/ \mathrm{u} /$ are dropped in an unstressed open syllable, but in this respect the Karaki dialect is very conservative: the older /a/ in the initial syllable in the nominal pattern $f a^{c} \bar{l} l$ is often retained and not dropped as the result of regressive assimilation: malīh 'good', $b a^{c} \bar{\imath} d$ 'distant, far away', samin 'fat', ša $a^{c} \bar{\imath} r$ 'barley', ğadīd 'new', even kabìr 'big', but I have only observed $k \underline{t} \bar{i} r$ 'much', not katitir;

- retained interdentals and retained gender distinction in the plural 2nd and 3rd persons of personal pronouns and verbs;

- the form hummu of the 3rd p. pl.m. of the personal pronoun, shared with Mādaba and es-Salt, see 1.1. above;

- $h \bar{e}<h \bar{e} \underline{d}$ 'this way, so', used side by side with $h \bar{e} k$, see 1.1. above;

- absence of compound negations. This trait, also typical of the closely related dialects spoken in Mādaba and eț-Ṭafîle, might at first sight be considered as a Bedouin feature. Among the sedentary bagūl dialects, these are the only ones which do not make use of them: ana mā gult he $k$ 'I didn't say that', la tgūl 'don't say', mā biddi 'I don't want', mā bì/fì 'there is not' ${ }^{44}$ Although Karaki shares this feature with the neighbouring Bedouin dialects, I would not consider it a Bedouin feature, but rather a conservative trait which it has in common with the Syrian sedentary dialects. The southern half of Lebanon, Hōrān, and the Syrian oases have $m \bar{a} b a^{c} r i f$ 'I don't know' and $m \bar{a} b a^{c}$ rif(a)šs side by side, whereas the northern half of Lebanon and the coastal Syrian dialects have $m \bar{a}$ $b a^{c}$ rif and $a b a^{c}$ rif side by side. ${ }^{45}$

\footnotetext{
40 Bergsträsser 1915, map 16.

41 Behnstedt 1997, map 284.

42 Palva 1980, 123.

43 Palva 1976, 30.

44 Palva 1989, 240.

45 Behnstedt 1997, map 225. As far as the history of the negative structures
} 
The compound negation may be a progressive feature in the Greater Syrian dialect area. Thus, Bergsträsser draws the southern boundary of this isogloss to the east of the river Jordan between ${ }^{\mathrm{c}} \mathrm{Ajlūn}$ and al-Balqa ${ }^{\mathrm{D}}$. According to him, the $-\check{s}$ component is obligatory only in Palestine proper. ${ }^{46}$ However, a comparison with old sedentary eastern Syrian dialects such as those of Palmyra, Soukhne, and il-Qaritēn, as well as the sedentary dialect spoken in Hōōān, shows that the compound negation in Saltị cannot plausibly be regarded as a recent borrowing from Palestinian dialects. ${ }^{47}$

- the sg.m. pattern $C \bar{a} C C$ of the active participle of the geminate verbs, used alongside $C \bar{a} C i C$, e.g. hătțt/hătitit; as in es-Salṭ and Ḥōrān; ${ }^{48}$

- the st. cstr. of the sg.f. active participle before a suffixed pronoun: kätbìtha/'she has written it,' which is shared with fellähi dialects in Transjordan and Ḥōrān; ${ }^{49}$

- min 'who?' in Karaki is a typically sedentary item, but there is another form which plausibly harks back to the shorter form *min: $m(i) n \bar{u}$, $m(i) n \bar{l}, m(i)$ nummu, (m(i)ninne); cf. eț-Ṭafìle *man: manhu, manhi. The form $m \overline{i n}$ in el-Karak might be suspected of being a K-form, all the more because the equivalent of $\mathrm{min}$ in es-Salt is $\mathrm{man} / \mathrm{min}$, which there

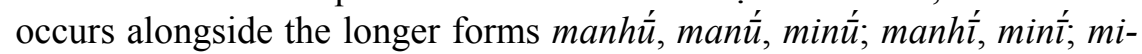
питти, тпитти. These, again, could be suspected as being loans from neighbouring Bedouin dialects (e.g. the Hwêtạat min plus enclitic personal pronoun: minhū, minhī, minhum, minhin, when used as copulae, all persons are used: minint 'who are you?' etc; Bani 'Ațiyye min; minh $\bar{u} l l i$

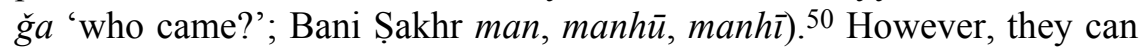
with good reason be regarded as inherited sedentary items, since forms of these kinds occur in Ḥōrān and Palmyra as well (Ḥōrān man, longer forms män hu, män hi, men hi ' ${ }^{\prime}{ }^{2} e^{i}$; Palmyra men, män, most often extended with a personal pronoun: men hī 'eče el-yōm 'who came today?', men $h \bar{u} h \bar{e}$ 'who is she?', men $h \bar{\imath}$ 'ontei 'who are you (sg.f.)?' but bèt men 'whose house?', baddek tšüf men 'whom do you want to see?', la men he्de 'whose is this?'). ${ }^{51}$ Furthermore, similar forms are attested also in

in the Syrian area is concerned, it is worth noticing that Cypriot Arabic does not use compound negations, Borg 1985, 148-149.

46 Bergsträsser 1915, map 21 and $\$ 53$.

47 Palva 2004, 234.

48 Cantineau 1946, 228.

49 Ibid., 223-225 and references there.

50 Palva 1984-1986, 298; id. 1980, 122-123; Bani ${ }^{\mathrm{c}}$ Ațiyye, own observation.

51 Cantineau 1946, 379-381; Cantineau 1934, 220-221; Behnstedt 1997, map 
the Mesopotamian qaltu dialects: mani Baghdad Jews, menu Baghdad Muslims and Christians; postposed enclitic elman 'whose?' Muslims, Imani Jews; Mosul menu, 'Āna and Hīt mān, the rural gilit dialects menhu, menhi; 52 the Anatolian group has mon *min invariable, mane *min-hū; and Dēr ez-Zōr mēn, minu. ${ }^{53}$ The situation in Hōōān is very illuminating, as stated by Behnstedt: a prestige form $\min$ is emerging; cf. Cantineau (1933-36): man, and Behnstedt (1988): otherwise man, but in the northeastern part of Hōōān, closer to Damascus, mīn. ${ }^{54}$ The occurrence of $\min$ in el-Karak is obviously an example of the same development.

- hassa' 'now' might be labelled as a rural item, which stands somewhere between sedentary and Bedouin dialects; it is a markedly Transjordanian and Ḥōrāni item of Syro-Mesopotamian Bedouin type vs. rural south and central/southwest Palestinian halhīn, halgèt, halqèt, Hebron $h_{a l} \bar{e} t$, Galilean and south Lebanese issa; hassa ${ }^{c}$ is used also in the northern part of central Palestine up to Jenin; cf. also Bedouin dialects:

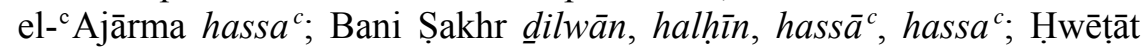
halhīn, hass $\bar{a}^{c}$, hass $\bar{a}^{c} a .55$ The Muslim, Jewish and Christian dialects of Baghdad have hassa, ${ }^{56}$ northern Israeli Bedouin hassa ${ }^{c}$, hassz; ${ }^{57}$ the sedentary Syrian dialects have different reflexes of *halwaqt, Palmyra, Soukhne, and Euphrates-group *(h)alhazz. ${ }^{58}$

\subsection{Karaki: Conclusion}

In purely synchronic terms, Karaki can with good reason be classified as a south Transjordanian rural dialect of mixed type, displaying affinities with Bedouin dialects spoken in Sinai and the Negev, as well as with those spoken in southern Jordan and to the east of the Gulf of Aqaba. It is worth noticing that it also displays several distinctive features shared by sedentary dialects spoken in Transjordan and Ḥōrān (see 2.4. below; among these, I have not attested $h \bar{e}<h \bar{e} \underline{d}$ in es-Salt).

From a diachronic point of view it seems justified to classify the dia-

289, gives mān (manu, mani) for Palmyra and Soukhne.

52 Blanc 1964, 137-138.

53 Jastrow 1978, 115; Behnstedt 1997, Map 289, gives only minu, mini; a few localities northeast of Damascus have mèn plus minu, mini.

54 Behnstedt 1997, map 289.

55 Palva 1976, 39; id. 1980, 132; id. 1984-1986, 304.

56 Blanc 1964, 140.

57 Rosenhouse 1984, 112.

58 Bergsträsser 1915, map 27; Behnstedt 1997, map 282; Fischer 1959, 150. 
lect of el-Karak as a sedentary southeast Palestinian dialect which in Bedouin environments has become partially bedouinized. ${ }^{59}$ We can safely assume that the bedouinization mostly took place in the sixteenth, seventeenth and eighteenth centuries, and when we consider the Bedouin elements presently occurring alongside sedentary elements, it also seems apparent that the dialect during the twentieth century has been drawing away from the Bedouin type.

2. The dialect of es-Salt ${ }^{60}$

2.1. Sedentary features in Salti

- the stress patterns and syllable structure are essentially identical with those obtaining in Palestinian sedentary dialects;

- systematic use of the $b$-imperfect to denote indicative non-past action and non-contingency; also the phonetic shape: bugül/bgūl instead of the supposed bigūl; pl. 1st p. mingūl;

- compound negation as an affective negation: $a-b i \check{s}$ 'there is not,' $a$ bihimmiš 'I don't care,' baḥkǐs 'I don't speak,' btacrifišš 'you don't know'; 61

- yōkil, yōxud vs. Bedouin yākil, yāxid;

- ăga vs. Bedouin ğa/iğa;

- short $n$-less imperfect forms bitgūli sg. 2nd p.f., bitgūlu pl. 2nd p.m., bugūlu pl. 3rd p.m. vs. Bedouin tigūlìn, tigūlūn, yigülūn respectively; note that many Bedouin dialects are giving up this final $-n ; 62$

- Forms V and VI itšarraf 'to be honoured', ithārab 'to fight, to be engaged in war' vs. Bedouin tišarraf, tih̆ārab;

- badd/bidd vs. Bedouin widd;

- $\check{s} \bar{u},{ }^{\circ} \bar{e} \check{s}$ vs. Bedouin wuš, wiš etc.;

- hēk, hēć, hēča 'this way, so' vs. Bedouin hīć;

- xamistiyyām 'five days' vs. Bedouin xams ayyām;

- xamisța ‘̌́ar yōm 'fifteen days' vs. Bedouin -ar-less;

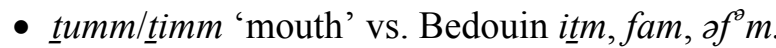

- 'what?' two invariable pronouns: $\check{s} \bar{u}, \check{s} u$ and ' $\bar{e} s$, ' $\supset \check{s}$; the short forms are used in proclitic positions. When used in isolation, $\check{s} \bar{u}$ is normally

59 The mutual influence between Bedouin Negev Arabic and Fellāhi Negev Arabic displays in several respects a parallel development, Henkin 2008, 360 and passim.

60 All Salti data are based on own observations.

61 For negative constructions in Salti, see Palva 2004.

62 Palva 1976, 32; in Karaki the $n$-less imperfect forms are no distinctive sedentary feature, as the Bedouin neighbours use these as well. 
lengthened with personal pronouns $\check{s} u h \bar{u}, \breve{s i h} \bar{\imath}$ 'what's that?', after a semantic shift 'what?'

- use of the genitive markers $t a b a^{c}$ and šit.

\subsection{Bedouin features in Salți}

- the voiced $g$ reflex of *q;

- the (partially retained) phonetically-conditioned variants $k / \check{c}$ of *k;

- yōm, temporal conjunction 'when,' used side by side with the sedentary Palestinian lamma; also lōm;

- badri, bidri, mbaddir 'early,' used side by side with the sedentarytype item bakkir;

- Bedouin high-frequency items, e.g.: ladd 'to look,' sōlaf 'to talk, narrate'.

\subsection{Conservative and locally restricted features in Salti}

- retained interdentals;

- retained gender distinction in plural of finite verbs and personal pronouns. This feature is shared with central and south Palestinian rural dialects; 63

- the form hummu of the 3rd p. pl.m. of the personal pronoun, shared with el-Karak and Mādaba, see 1.1. above;

- imbāreh, also ams 'yesterday'; if the informants are right when claiming that the latter is a genuine local item, it is a regressive, or even recessive, feature. However, more probably it is a Bedouin trait. ${ }^{64}$

- bukra, gadd 'tomorrow'; according to Cantineau, gadd is "l'expression véritablement ḥōrānaise pour 'demain'." 65 In Palmyra and Soukhne 'tomorrow' is bukra and bučra, respectively, whereas $\dot{g} a d d$ is not attested. ${ }^{66}$ Bauer reports the occurrence of $\dot{g} a d d$ among the central Palestinian fellāhin, used side by side with bučra. ${ }^{67}$ Here the Bedouin influence is out of question, because in the neighbouring Bedouin dialects this item is $b \bar{a} k i r, b \bar{a} c i r, b \bar{a} c i r$. Thus $\dot{g} a d d$ is probably a genuine, recessive feature which has only sporadic traces in rural Palestinian, Transjordanian and Ḥōrāni dialects.

- the sg.m. pattern $C \bar{a} C C$ of the active participle of the geminate verbs, used alongside $C \bar{a} C i C$, as in el-Karak and Ḥōrān;

\footnotetext{
63 Bauer 1926, 18, 67; Schmidt-Kahle 1917, 64*, 73*.

64 See footnotes 36-39 above.

65 Cantineau 1946, 394-395.

66 Cantineau 1934, 228; Behnstedt 1994, 214.

67 Bauer 1926, 93.
} 
- the st. cstr. of the sg.f. active participle before a suffixed pronoun: kātbìtha 'she has written it'; ana hätțitha ca-l-hẹt 'I hanged it on the wall,' a feature shared by fellăhi dialects in Transjordan and Hōōān;

- 'who?' is interestingly short-vocalic: $\mathrm{man} / \mathrm{min}$ and $\operatorname{manh} \dot{\bar{u}}, \mathrm{man} \bar{u}$,

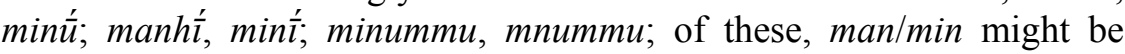
suspected of being a loan from neighbouring Bedouin dialects, but more likely it is a genuine old sedentary form characteristic of Transjordan and Hōōān.

- mèt(a), amèt, wēmta 'when?' vs. Bedouin mita; conjunction mēt-ma. Among the variants, wèmta is a very widely used form in SyroPalestinian sedentary dialects, and in Salti it could be regarded as a Kform, whereas mèt(a) and amèt are old local forms characteristic of sedentary dialects in central and northern Transjordan as well as in Ḥōrān. ${ }^{68}$ - the genitive marker šit , used side by side with the more general $t a b a^{c}$, which is the most common form in the Greater Syrian sedentary dialect area; šit and šiyyit are also attested in a restricted area around Damascus. ${ }^{69}$ Another variant is šett, pl. šayyūt, given for Palestine ('mostly urban') by Bauer, used alongside $t a b a^{c}$ ('more urban') and ('fellähi'). ${ }^{70}$ Arnold reports the same forms from Jaffa and its neighbourhood. ${ }^{71}$ That the genitive marker $*_{\text {šay }}{ }^{\circ}+t$, which at the present is a recessive item, has a thousand-year history in sedentary Syrian and Palestinian Arabic is well documented by its occurrence in Cypriot Arabic, where it occurs in the forms šayt- and $\check{s} a t-.72$

\subsection{Salti: conclusion}

Among the typologically distinctive features of Saltị, rural central Palestinian traits are predominant. However, Salti also displays more eastern sedentary features several of which it shares with el-Karak, such as hätt kātbìtha; hummu; man/min, manh $\bar{u}$, manú, etc. The forms mêt(a), amēt belong to the same category, but I have not attested them in el-Karak. The recessive gadd may in the past have been used also in Palestine, and the regressive $s \bar{\imath} t$ with its varieties has obviously been commonly used 290.

68 Bergsträsser 1915, map 26; Cantineau 1946, 394; Behnstedt 1997, map

69 Behnstedt 1997, map 249. According to Grotzfeld 1965, 92, this genitive modifier is dying out.

70 Bauer 1926, 72; it occurs also in Schmidt and Kahle 1930, 170, line 5.

71 The urban varieties are $t a b a^{c}$ and $\check{s} \bar{e} t$. In villages, only the latter is used, Arnold 2004, 41.

72 Borg 1985, 130-131; id. 2006, 536-537. 
in sedentary dialects of Greater Syria. Distinctive Bedouin traits in Salți are rather few, among them the $g$ reflex of $* \mathrm{q}$, the most prominent Bedouin marker. It is likely that in the Bedouin-dominated sixteenth to midnineteenth centuries the $g$ reflex became dominant in Salți. Its affricated variant was, however, not adopted, perhaps due to the heterogeneity of the population, ${ }^{73}$ admittedly not substantial, but still large enough to suppress the affrication development. The case may also be compared to the more recent developments in Amman, where the $g$ variant is 'associated with toughness, manhood and masculinity' and therefore has 'some prestige among male speakers of all backgrounds' ${ }^{74}$ Although the $g$ reflex in Amman is perceived as a Bedouin trait and as such has some prestige among male speakers, the prestige is restricted to this particular feature alone. It does not comprise the exclusively Bedouin-type affricated reflex, which implies that Bedouin dialects as such are not regarded as prestigious. In es-Salt the development may well have followed the same outlines. To be sure, the linguistic adaptation was mutual: the sedentary $b$-imperfect was adopted as the local standard also by speakers of Bedouin origin, and the result was a mixed bugūl type dialect.

As to the reflexes of $* \mathrm{k}$, it is uncertain whether $\check{c}$ ever became fully established. According to Bergsträsser, at the beginning of the twentieth century an urban dialect was in the early stages, and the educated 'already' used only the unaffricated reflex. ${ }^{75}$ It is possible that apart from a few cases, e.g. the grammaticalized feminine morpheme $-(i) \check{c}$, the feminine demonstrative pronoun had $\bar{i} \check{c}(e)$, the particle čān, čann-/kann-, inčān/inkān, and the salutation čêf hălak, f. hălič 'how are you?'76 the combinatorily conditioned affrication among a part of the population always remained a marginal feature. In any event, it is still freely used by uneducated women and children in the villages around the town. Outside the intimate circle, the affricated variant $\breve{c}$ has become a stigmatized variant which is probably bound to die out in the course of two or three generations. Interestingly, it is both a Bedouin trait and a central Palestinian fellăhi feature, and stigmatized because of the latter.

\footnotetext{
73 So explained by Abdel-Jawad $(1981,164-165)$ for present-day Amman.

74 Abdel-Jawad 1981, 176-177, 336; for the ambiguous prestige of the urban vernaculars particularly among male immigrants, see Miller 2004, 196-197.

75 'Die Städte haben im ganzen Land $k$; auch in es-Salt sprechen die Gebildeten bereits $k$, hier ist ein städtischer Dialekt noch im Entstehen'. Bergsträsser 1915, 185.

76 Palva 1994, 466, 468.
} 


\section{A diachronic reflexion}

In the concurrence between rural (Bedouin and peasant) and urban dialects in el-Karak and es-Salt, the rural dialects have prevailed: the interdentals and the gender distinction in plural of finite verbs and personal pronouns have been retained. In es-Salt, the rural-type affrication of $k$ is mainly suppressed, probably as a result of a slowly progressing urbanization process. Generally speaking, in the districts of al-Balqa ${ }^{j}$ and elKarak, the contrasts between the sedentary and the Bedouin dialects are not very sharp. Unfortunately, the reports from the area before the twentieth century do not include any detailed linguistic information. Thus, when Burckhardt characterized the Salti and Karaki as Bedouin dialects, it does not necessarily imply more than an impression concerning the difference between the sedentary Syro-Palestinian dialects and those spoken in es-Salt and el-Karak. It may be noted that he a few months earlier had travelled in Hōrān, and writes that the local peasants had 'adopted, for the greater part, the bedouin dialect, gestures, and phraseology'. ${ }^{77}$ We can speculate, but not give conclusive evidence, that the Salți and Karaki dialects two hundred years ago, after a lengthy period of bedouinization, really had more Bedouin features than today, after a period of re-sedentarization since the latter part of the nineteenth century, and dialect levelling during the past two generations.

\section{REFERENCES}

Abdel-Jawad, Hassan Rashid E. 1981. Lexical and Phonological Variation in Spoken Arabic of Amman. Unpubl. Ph.D. diss., University of Pennsylvania.

Arnold, Werner. 2004. 'Die arabischen Dialekte von Jaffa und Umgebung'. Approaches to Arabic Dialects. A Collection of Articles Presented to Manfred Woidich on the Occasion of his Sixtieth Birthday, ed. by Martine Haak, Rudolf de Jong and Kees Versteegh. 33-46. Leiden and Boston: Brill.

Bauer, Leonhard. 1926. Das palästinische Arabisch. Die Dialekte des Städters und des Fellachen. 4. Aufl. Leipzig: Hinrichs.

Behnstedt, Peter. 1994. Der arabische Dialekt von Soukhne (Syrien). II. Phonologie, Morphologie, Syntax. III. Glossar. Wiesbaden: O. Harrassowitz.

—. 1997. Sprachatlas von Syrien. Kartenband. Wiesbaden: O. Harrassowitz.

\footnotetext{
77 Burckhardt 1822, 291-292.
} 
Bergsträsser, Gotthelf. 1915. 'Sprachatlas von Syrien und Palästina'. Zeitschrift des Deutschen Palästina-Vereins 38: 169-222 + 42 Karten.

Blanc, Haim. 1964. Communal dialects in Baghdad. Cambridge, Mass.: Harvard University Press. (Harvard Middle Eastern Monographs, X.)

—. 1970. 'The Arabic dialect of the Negev Bedouins.' The Israel Academy of Sciences and Humanities. Proceedings, 4/7: 112-150.

Borg, Alexander. 1985. Cypriot Arabic. Stuttgart: Franz Steiner. (AKM XLVII, 4.)

—. 2006. 'Cypriot Maronite Arabic.' Encyclopedia of Arabic Language and Linguistics. General Editor Kees Versteegh, vol. I: 536-543. Leiden and Boston: Brill.

Burckhardt, John Lewis. 1822. Travels in Syria and the Holy Land. London: Murray. (Reprinted 1992: Darf Publishers Ltd).

Cantineau, Jean. 1934. Le Dialecte arabe de Palmyre. T. I. Grammaire. Beyrouth: Maisonneuve. (Mémoires de l'Institut Français de Damas).

—. 1946. Les Parlers arabes du Hōrān: Notions générales, grammaire. Paris: Klincksieck.

Cleveland, Ray L. 1967. 'Notes on an Arabic dialect of Southern Palestine', Bulletin of the American Schools of Oriental Research 185, 4357.

Dā̄ūd, Jūrj Farīd Ṭarīf. 1994. al-Salt wa-jawāruhā xilāl al-fatra 18641921. In 1993 presented as Ph.D. diss., University of Jordan. Amman: Silsilat manšūrāt Bank al- ${ }^{\circ} \mathrm{a}^{\mathrm{c}}$ māl.

Fischer, Wolfdietrich. 1959. Die demonstrativen Bildungen der neuarabischen Dialekte. Ein Beitrag zur historischen Grammatik des Arabischen. The Hague: Mouton and Co.

Grotzfeld, Heinz. 1965. Syrisch-arabische Grammatik. Wiesbaden: Otto Harrassowitz.

Gubser, Peter. 1973. Politics and Change in al-Karak, Jordan. A Study of a Small Arab Town and its District. London: Oxford University Press.

Henkin, Roni. 2008. 'Negev Arabic'. Encyclopedia of Arabic Language and Linguistics, General Editor Kees Versteegh, vol. III: 360-369. Leiden and Boston: Brill.

Hütteroth, Wolf-Dieter, 1978. Palästina und Transjordanien im 16. Jahrhundert. Wirtschaftsstruktur ländlicher Siedlungen nach osmanischen Steuerregistern. Wiesbaden: Dr. Ludwig Reichert. (Beihefte zum Tübinger Atlas des Vorderen Orients, Reihe B Geisteswissenschaften, Nr. 33). 
Jastrow, Otto. 1978. Die mesopotamisch-arabischen qaltu-Dialekte. Band I: Phonologie und Morphologie. Wiesbaden: Kommissionsverlag Franz Steiner Gmbh.

Jaussen, Antonin. 1948 (1907). Coutumes des arabes au pays de Moab. Paris: Adrien-Maisonneuve.

Khuraysāt, Muḥammad ' Abd al-Qādir. 1986. 'al-Salṭ. Dirāsa c umrāniyya bašariyya min xilāl sijillāt al-mạ̣kama al-šar'iyya fī l-Salṭ 12991345/1881-1926'. Dirāsāt. Humanities. A Learned Research Journal Published by the University of Jordan, 13/4: 61-105.

Miller, Catherine, 2004. 'Variation and Change in Arabic Urban Vernaculars'. Approaches to Arabic Dialects. A Collection of Articles Presented to Manfred Woidich on the Occasion of his Sixtieth Birthday, eds. Martine Haak, Rudolf de Jong and Kees Versteegh, pp. 177206. Leiden and Boston: Brill.

Musil, Alois. 1908. Arabia Petraea. III. Ethnologischer Reisebericht. Wien: Kaiserliche Akademie der Wissenschaften, in Kommission bei Alfred Hölder.

Oppenheim, Max von. 1943. Unter Mitarbeitung von Erich Bräunlich und Werner Caskel. Die Beduinen. Band II. Die Beduinenstämme in Palästina, Transjordanien, Sinai, Hedjāz. Leipzig: O. Harrassowitz.

Palva, Heikki. 1976. Studies in the Arabic Dialect of the Semi-Nomadic al- ${ }^{c}$ Ağārma Tribe (al-Balq $\bar{a}^{\supset}$ District, Jordan). Göteborg: Acta Universitatis Gothoburgensis. Orientalia Gothoburgensia 2.

—. 1980. 'Characteristics of the Arabic Dialect of the Bani Saxar Tribe', Orientalia Suecana 29: 112-139.

—. 1984-1986. 'Characteristics of the Arabic Dialect of the Hwẹtāt Tribe', Orientalia Suecana 33-5: 295-312.

—. 1989. 'Linguistic Sketch of the Arabic Dialect of el-Karak', Studia linguistica et orientalia memoriae Haim Blanc dedicata, ed. Paul Wexler, Alexander Borg, Sasson Somekh, 225-251. Wiesbaden: Harrassowitz.

—. 1991. 'Is there a North West Arabian Dialect Group?' Festgabe für Hans-Rudolf Singer. Hrsg. Martin Forstner. Teil 1, 151-166. Frankfurt am Main and al.: Peter Lang.

—. 1994. 'Bedouin and Sedentary Elements in the Dialect of es-Salt'. Actes des premières journées internationales de dialectologie arabe de Paris. Édités par Dominique Caubet et Martine Vanhove, 459-469. Paris: INALCO.

—. 1997. 'Linguistic Observations of the Explorers of Arabia in the 19th Century.' Built on Solid Rock. Studies in Honour of Professor 
Ebbe Egede Knudsen on the Occasion of his 65th Birthday April 11th 1997, ed. Elie Wardini, 226-239. Oslo: Novus Forlag.

- 2004. 'Negations in the Dialect of es-Salț, Jordan', Approaches to Arabic Dialects. A Collection of Articles Presented to Manfred Woidich on the Occasion of his Sixtieth Birthday, ed. Martine Haak, Rudolf de Jong and Kees Versteegh, 221-236. Leiden and Boston: Brill.

- 2008. 'Northwest Arabian Arabic', Encyclopedia of Arabic Language and Linguistics, General Editor Kees Versteegh, vol. III: 400408. Leiden and Boston: Brill.

Peake, Frederick G. 1958. History and Tribes of Jordan. Coral Gables, Flor.: University of Miami Press.

Rosenhouse, Judith. 1984. The Bedouin Arabic Dialects. General Problems and a Close Analysis of North Israel Bedouin Dialects. Wiesbaden: O. Harrassowitz.

Schmidt, Hans and Paul Kahle (Hrsg.). 1918. 2. Band 1930. Volkserzählungen aus Palästina, gesammelt bei den Bauern von Bir-Zet und in Verbindung mit Dschirius Jusif in Jerusalem hrsg. Göttingen: Vandenhoeck und Ruprecht. 